\title{
KEBEBASAN PEKERJA DALAM MENJALANKAN IBADAH DI KAWASAN INDUSTRI
}

\author{
Ikhwan Aulia Fatahillah \\ Fakultas Syariah dan Hukum UIN Sunan Gunung Djati Bandung \\ E-mail: ikhwanaf@uinsgd.ac.id
}

\begin{abstract}
Implementation of Law No. 13 of 2003 on manpower is interesting to do because the company has violated and does not provide freedom for employees to exercise their religious beliefs. The limitation of worship facilities in the workplace is one of the forms of how the company has no commitment to implementation of the by that have been laid down. The research on freedom of worship of the workers has chosen a place, namely in Bekasi Regency. The purpose of this research is to provide a deep description and understanding of freedom in the conduct of the worship of workers under the Law No. 13 of 2003 on employment in freedom of exercise of religious obligations for the workers in Bekasi regency. This research uses a Quali-tatif method and gives birth to the Keismpulan namely (1) companies that become a site of research in Bekasi has provided the facilities and infrastructure of worship as stipulated Act No. 13 of 2003 on employment in freedom of exercise of religious obligations. Nevertheless, on the other hand, the workers still expect the improvement of the quality and quantity of worship facilities so that it can run the worship more comfortably; and (2) in general, consciousness worships the workers at levels or levels. That is to say, they have faith in God with minimal knowledge of faith. They also carry out religious practices as evidence of the faith itself and as evidence of obedience to God.
\end{abstract}

\section{Keywords:}

awarness, employment, religious obligations 


\begin{abstract}
Abstrak
Implementasi Undang-Undang Nomor 13 Tahun 2003 tentang Ketenagakerjaan menjadi menarik dilakukan karena kerapkali perusahaan melanggar dan tidak memberikan kebebasan untuk para pegawai dalam menjalankan keyakinan agamanya. Keterbatasan sarana ibadah di tempat kerja pun merupakan salah satu bentuk bagaimana perusahaan tidak memiliki komitmen terhadap implementasi atauran yang telah diundangkan. Penelitian mengenai kebebasan beribadah kaum pekerja ini memilih tempat, yaitu di Kabupaten Bekasi. Tujuan penelitian ini untuk memberikan deskripsi dan pemahaman secara mendalam mengenai Kebebasan Dalam Menjalankan Beribadah Pekerja Dihubungkan Undang-Undang Nomor 13 Tahun 2003 tentang Ketenagakerjaan Dalam Kebebasan Menjalankan Kewajiban Beragama Bagi para kaum pekerja di Kabupaten Bekasi. Penelitan ini menggunakan metode kualitatif dan melahirkan keismpulan yakni (1) perusahaan-perusahaan yang menjadi tempat penelitan di Kabupaten Bekasi sudah menyediakan sarana dan prasarana ibadah sebagaimana diatur Undang-Undang Nomor 13 tahun 2003 tentang Ketenagakerjaan dalam Kebebasan Menjalankan Kewajiban Beragama. Namun demikian, di sisi lain, para buruh masih mengharapkan perbaikan kualitas dan kuantitas sarana ibadah sehingga dapat menjalankan ibadah lebih nyaman; dan (2) secara umum, kesadaran beribadah para pekerja berada pada tingkat atau level biasa. Artinya, bahwa benar mereka beriman kepada Allah dengan pengetahuan keimanan yang minimal. Mereka juga melaksanakan praktik agama sebagai bukti dari keimanan itu sendiri dan sebagai bukti ketaatan kepada Allah.
\end{abstract}

\title{
Kata-kata kunci:
}

kesadaran, ketenagakerjaan, kewajiban beragama 


\section{Pendahuluan}

Pada negara Indonesia, industrialisasi merupakan suatu keniscayaan. ${ }^{1}$ Barometer negara berkembang atau bahkan negara maju sekalipun dilihat dari seberapa besar penyerapan pada sektor industri dalam rangka mensejahterakan masyarakat. Sebab tugas negara pada dasarnya adalah menciptakan kesejahteraan melalui bebagai kebijakan, regulasi serta tindakan yang selalu mengedapankan kepentingan rakyat. $^{2} \mathrm{Di}$ Indonesia, proses industrialisasi dimulai sejak pemerintahan Orde Baru hingga saat ini Orde Reformasi. Industrialisasi kerapkali dimaknai sebagai proses masuknya modal asing untuk membangun pabrik-pabrik berkapasitas besar dengan melibatkan ribuan karyawan sebagai tenaga kerjanya.

Bila dilihat secara ekonomi, ada beberapa keuntungan yang dapat dipetik dari industrialisasi tersebut, misalnya: Pertama, industrialisasi meningkatkan pendapatan nasional yang pada gilirannya memberikan dampak signifikan terhadap kesejahteraan rakyat. Kedua, industrialisasi menyediakan lapangan kerja yang melimpah sehingga dapat menyerap tenaga kerja (usia produktif) baik pada sektor industri tersebut maupun sektor lain seperti perdagangan. Ketiga, industrialisasi akan meningkatkan daya saing nasional sehingga negara mempunyai keunggulan kompetitif berdasarkan keunggulan komparatif dengan mengacu kepada pengembangan klaster industri, sehingga tercipta struktur industri yang kokoh dan seimbang. Keempat, industrialisasi menciptakan profesionalisme pelaku usaha dan kelembagaan perdagangan, sehingga kegiatan perdagangan barang dan jasa di dalam negeri semakin berkembang. Kelima, industrialisasi menciptakan iklim usaha yang kondusif dengan menerapkan mekanisme pasar tanpa distorsi, serta terjaminnya perlindungan konsumen sehingga tercipta pemahaman konsumen akan hak dan kewajibannya dalam upaya tertib mutu, tertib usaha dan tertib ukur. Keenam, industrialisasi memacu peningkatan kemampuan profesionalisme sumber daya manusia, penguasaan penggunaan teknologi dan inovasi, serta pemenuhan ketentuan standar keamanan, kesehatan, dan lingkungan baik nasional maupun internasional. Kudus, 1.

${ }^{1}$ M. Arif Hakim, Industrialisasi di Indonesia Menuju Kemitraan yang Islami, STAIN

${ }^{2}$ Yohanes Suhardin, Peranan Negara dan Hukum dalam Memberantas Kemiskinan dengan Mewujudkan Kesejahteraan Umum, Jurnal Hukum dan Pembangunan Tahun ke-42 No.3 Juli-September 2012, 1-2. 
Bila dilihat dari enam hal di atas, betapa industrialisasi memberikan banyak manfaat bagi pertumbuhan masyarakat, bangsa dan negara dari sisi ekonomi dan pemanfaataan sumber daya manusia. Persoalan tenaga kerja semakin mendapat tantangan besar manakala saat ini Indonesia menghadapi MEA (Masyarakat Ekonomi Asean) ${ }^{3}$. Kehadiran MEA tidak saja memberikan harapan bahwa tenaga kerja Indonesia dapat berkiprah di luar negeri, tetapi pada saat yang sama memberikan ancaman, dalam arti persaingan untuk mendapatkan peluang kerja harus bersaing dengan tenaga kerja dari negeri tetangga.

Kabupaten Bekasi merupakan wilayah yang saat ini menjadi bagian wilayah industrialisasi nasional. ${ }^{4}$ Di kabupaten tersebut banyak berdiri pabrik-pabrik berskala nasional maupun multi nasional yang menyerap ribuan tenaga kerja. Penyerapan tenaga kerja oleh perusahaan memberikan dampak positif terhadap peningkatan kesejahteraan masyarakat, baik masyarakat setempat maupun masyarakat pendatang (urban). Secara makro, stabilitas suatu kawasan akan memiliki tingkat stabilitas yang tinggi apabila perekonomian stabil pula.

Bila satu sisi kehadiran industrialisasi yang berwujud pabrikpabrik dengan melibatkan tenaga kerja yang besar mampu memberikan kesejahteraan bagi masyarakat, tetapi di sisi lain menimbulkan persoalan yang tidak kalah pelik. Pekerja pabrik misalnya, memiliki jam kerja yang ketat sebagai derivasi dari sistem perusahaan yang lebih mengutamakan efektivitas dan efisiensi dengan disiplin kerja yang sangat tinggi. Akibatnya, pekerja menjelma menjadi semacam "robot" yang sangat terkontrol untuk menghasilkan kinerja yang tinggi. Waktu kerja yang terjadwal ketat pada bagian lain berimbas kepada pelaksanaan ibadah ritual sebagai kewajiban dari setiap insan yang beragama.

Menjalankan syariat agama dalam berbagai bentuknya tidak saja dimaknai sebagai sebagai cermin dari kesalehan pribadi, tetapi lebih jauh memiliki dampak terhadap kepada kesalehan sosial. Seseorang yang menjalankan syariat agama harus mampu menghadirkan dirinya

3 MEA Sebuah terobosan baru dimana perdagangan bebas antar negara negara ASEAN disahkan secara resmi. Dalam bahasa inggris, MEA dikenal dengan nama ASEAN Economic Community (AEC), yang mana AEC atau MEA ini disiapkan untuk mewujudkan integrasi wawasan ASEAN 2020. Tentunya masyarakat ekonomi ASEAN ini telah disepakati oleh seluruh negara negara ASEAN yang menjadi anggotanya. Lihat http://blogpengertian. com/mea-adalah-masyarakat-ekonomi-asean/

${ }^{4}$ B. Saleh dan L. Warlina, Identifikasi Karaktreristik Aglomerasi Industri Pengolahan di Cikarang Kabupaten Bekasi Tahun 2006-2013, Jurnal Wilayah dan Kota, Volume 4 Nomor 1, 2. 
sesuai dengan nilai-nilai agama yang dianutnya. Bahkan secara kualitatif, keberagamaan yang tinggi akan memberikan dampak positif terhadap kinerja di tempat kerjanya. ${ }^{5}$

Sejatinya, siapa pun termasuk kaum pekerja, memiliki hak dalam menunaikan ibadah dan keyakinannya sebagai pengejawantahan dari nilainilai Pancasila, UUD 19456, dan Undang-undang Nomor 13 Tahun 2003 tentang Ketenagakerjaan Dalam Kebebasan Menjalankan Kewajiban Beragama. Hak menunaikan ibadah adalah hak dasar yang dijamin sebagaimana tercantum pada pasal 29 UUD 1945. Penelitian mengenai kebebasan kaum pekerja ini memilih tempat, yaitu di kabupaten Bekasi. Adapun beberapa pertimbangan dalam penentuan tempat ini adalah bahwa Kabupaten Bekasi adalah kabupaten yang telah lama menjadi wilayah indutri di Jawa Barat. Oleh karena itu, dinamika tentang implementasi peraturan mengenai ketenagakerjaan tersebut sangat mungkin tarikmenarik dan menimbulkan diskursus yang melibatkan banyak pihak.

\section{Metodologi}

Penelitian ini menggunakan paradigma konstruktivis, di mana realitas pada dasarnya tidak terjadi apa adanya melainkan dibangun atau dikonstruksi melalui cara-cara tertentu sebagaimana yang diharapkan dengan metode kualitatif dengan tujuan untuk dapat mengungkap realitas yang terjadi. Data dikumpulkan melalui observasi nonpartisipan dan wawancara mendalam. Sedangkan analisis data dilakukan secara terusmenerus selama penelitian berlangsung, dimulai sejak perumusan masalah hingga penulisan hasil penelitian. Proses analisis data harus dimulai dengan menelaah seluruh data yang tersedia dari berbagai sumber, data tersebut dibaca, dipelajari, dan ditelaah ${ }^{7}$. Untuk kepentingan penelitian ini, analisis data yang digunakan mengacu kepada teknik analisis interaktif Miles dan Huberman. Teknik ini disebut interactive model yang pada dasarnya terdiri dari tiga komponen, yaitu reduksi data (data reduction), penyajian data (data display), dan penarikan serta pengujian kesimpulan (drawing and verifying conclusions).

${ }^{5}$ Suhendri, Pengaruh Keberagaman Tenaga Kerja dan Lingkungan Kerja Terhadap Kinerja Karyawan (PT. Parkland World Indonesia Plants 2), STIE Prima Graha, 2.

${ }^{6}$ Pasal 29 UUD 1945 yang menegaskan bahwa negara berdasar atas Ketuhanan Yang Maha Esa serta negara menjamin kemerdekaan tiap-tiap penduduk untuk memeluk agamanya masing-masing dan untuk beribadat menurut agamanya dan kepercayaannya itu.

${ }^{7}$ Moleong, Metodologi Penelitian Kualitatif, (Bandung, Rosdakarya, 2006), hlm. 247 


\section{Hasil Penelitan dan Pembahasan}

Hasil penelitian mengkaji dalam dua bagian, bagian pertama berkaitan dengan Penerapan Undang-undang Nomor 13 Tahun 2003 tentang Ketenagakerjaan, dalam kebebasan menjalankan kewajiban beragama, bagian kedua terkait dengan kebebasan dengan berbagai dimensinya.

Pada perusahaan-perusahaan yang jumlah karyawannya banyak dibangun masjid yang representatif guna menampung pelaksanaan ibadah seperti shalat Jum'at. Sementara di beberapa bagian (gedung) tersedia juga mushala yang dapat menampung jumlah orang terbatas. Pada hari-hari biasa, pelaksanaan ibadah shalat dilakukan secara bergantian. Umumnya perusahaan memiliki mekanisme yang telah diatur sedemikian rupa sehingga antara pelaksanaan ibadah dan sistem kerja perusahaan dapat berjalan secara baik dan teratur.

Manajemen berharap bahwa dengan memberikan fasilitas ibadah dapat membangun pribadi-pribadi yang taat beragama sehingga berimbas kepada tanggung jawab dalam melaksanakan pekerjaan di pabrik (perusahaan). Orang-orang yang taat beragama akan lebih memiliki tanggung jawab dan berpikir bahwa pekerjaan sebagai sarana untuk beribadah $^{8}$.

Pada beberapa perusahaan berskala besar sarana dan prasarana ibadah sudah cukup memadai. Namun untuk beberapa perusahaan ada juga yang "kurang nyaman", terutama dengan ketersediaan kuantitas sarana ibadah bagi perempuan. Salah seorang informan perempuan menjelaskan tentang kenyamanan itu misalnya dari mushola yang reltif kecil serta fasilitas tenpat wudlu serta mukena yang tersedia ${ }^{9}$.

Namun secara keseluruhan sarana dan prasarana ibadah pada beberapa perusahaan yang menjadi tempat penelitian sudah cukup memadai. Artinya perusahaan telah menjalankan kewajibannya dalam menyediakan sarana ibadah guna menjamin hak-hak karyawan. Dengan demikian dapat disimpulkan bahwa Undang-undang Nomor 13 Tahun 2003 tentang Ketenagakerjaan telah dijalankan oleh perusahaan. Adapun terdapat beberapa kekurangan sarana yang lain tidak menjadi hambatan yang berarti sehingga tidak mengurangi hak-hak karyawan

${ }^{8}$ Hasil Penelitian Lapangan yang diperoleh penulis dari Wawancara dengan Informan Kabupaten Bekasi pada tanggal 3 November 2019 Pukul 09.45 WIB.

9 Hasil Penelitian Lapangan yang diperoleh penulis dari Wawancara dengan Informan Kabupaten Bekasi pada tanggal 3 November 2019 Pukul 09.45 WIB. 
dalam beribadah. Mereka berharap seiring waktu fasilitas ibadah dapat terus diperbaiki dan ditingkatkan lebih baik lagi.

Berkenaan dengan itu, salah seorang informan di Kabupaten Bekasi mengungkapkan, bahwa perusahaan memberikan waktu untuk menjalankan ibadah shalat sehari-hari kurang lebih tiga puluh menit, kecuali untuk hari jum'at (Jum'atan). Waktu itu harus kami manfaatkan sebaik-baiknya untuk dapat menunaikan shalat dan sedikit istirahat. Adanya fasilitas seperti masjid, mushala dan tempat wudhu yang representatif dapat membantu kami dalam mengefisienkan waktu. Oleh karena itu, saya memastikan bahwa pakaian yang saya pakai dalam keadaan suci sehingga dapat langsung mendirikan shalat ${ }^{10}$.

\section{Dimensi Keyakinan Agama}

Dimensi keyakinan agama menjadi bagian terpenting bagi seseorang dalam mengaktualisasikan keagamaannya itu pada ranah konkret. ${ }^{11}$ Amaliyah agama harus didasari oleh suatu keyakinan bahwa seluruhnya dalam rangka beribadah kepada Allah SWT. Agama apapun, teruatama Islam dimuai dari keyakinan yang dalam bahasa agama dikatakan sebagai iman. Kata "iman" dari bahasa Arab yang artinya percaya. Sedangkan menurut istilah, pengertian iman adalah membenarkan dengan hati, diucapkan dengan lisan, dan diamalkan dengan tindakan (perbuatan). ${ }^{12}$ Dengan demikian, pengertian iman kepada Allah adalah membenarkan dengan hati bahwa Allah itu benar-benar ada dengan segala sifat keagungan dan kesempurnaan-Nya, kemudian pengakuan itu diikrarkan dengan lisan, serta dibuktikan dengan amal perbuatan secara nyata. Jadi, seseorang dapat dikatakan sebagai mukmin (orang yang beriman) sempurna apabila memenuhi ketiga unsur keimanan di atas.

Hasil wawancara kepada sejumkah informan menggambarkan bahwa para pekerja atau karyawan adalah mereka yang secara kultur sebagai individu-individu yang religius (taat menjalankan agama), meskipun dalam

${ }^{10}$ Hasil Penelitian Lapangan yang diperoleh penulis dari Wawancara dengan Informan Kabupaten Bekasi pada tanggal 3 November 2019 Pukul 09.45 WIB.

11 Laode Monto Bauto, Perspektif Agama dan Kebudayaan dalam Kehidupan Masyarakat Indonesia (Suatu Tinjauan Sosiologi Agama), Jurnal Pendidikan Ilmu Sosial Volume 23 Nomor 2 Edisi Desember 2014, 4.

${ }^{12}$ Siti Muhayati, Ratih Christiana, dkk, Iman kepada Allah dan Perhatian Orang Tua Terhadap Budaya Nyontek Anak Usia Sekolah Dasar, Jurnal Bimbingan dan Konseling, 2. 
batas-batas yang masih perlu untuk ditingkatkan. Dalam konteks peningkatan keimanan ini, maka seorang hamba harus senantiasa memperdalam aspek keilmuannya sehingga pengetahuan tentang agamanya meningkat ${ }^{13}$.

Untuk dimensi keyakinan ini ditanyakan kepada lebih dari sepuluh orang informan, dan hasilnya memberikan deskripsi yang sama bahwa mereka menjalankan syariat agama berdasarkan atas keyakinan kepada Allah SWT. Meskipun mereka secara akademik tidak terlalu tinggi, tetapi ketika dihadapkan kepada pertanyaan tentang Allah mereka memberikan jawaban serupa, yaitu percaya akan dzat Allah yang maha menentukan.

Sebagai bentuk keimananan kepada Allah, mereka tetap menjalankan syariat agama seperti shalat di tengah-tengah pekerjaan dengan waktu kurang lebih tiga puluh menit. Pada suatu waktu peneliti mengamati ketika memasuki dzuhur mereka berbondong-bondong ke tempat shalat secara bergantian. Dari wajahnya mereka nampak lelah, tetapi tetap menjalankan ibadah shalat dengan suka cita. Meskipun di sisi lain ada juga yang yang tidak bergegas ke masjid, dan itu sangat mungkin mereka bukan muslim, atau sedang berhalangan bagi perempuan, atau mungkin ada alasan lain.

Pada dimensi keyakinan agama ini, hasil penelitian menggambarkan bahwa tingkat keyakinan mereka kepada Allah sangat baik dengan indikator verbal yang dibuktikan dengan hasil wawancara dan dibuktikan melalui hasil observasi. Dalam pemahaman peneliti, dalam batas-batas yang agak ideal para pekerja memahami tentang dimensi keyakinan ini yang menempatkan Allah sebagai dzat yang harus disembah. Sedangkan secara istilah ilmu Tauhid ialah ilmu yang membahas segala kepercayaan-kepercayaan yang diambil dari dalil-dalil keyakinan dan hukum-hukum di dalam Islam termasuk hukum mempercayakan Allah itu esa. ${ }^{14}$

\section{Dimensi Praktik Agama}

Pada dasarnya, praktik-praktik keagamaan mencakup dua hal, yaitu ritual dan ketaatan. Dimensi praktik agama menjadi kelanjutan

${ }^{13}$ Hasil Penelitian Lapangan yang diperoleh penulis dari Wawancara dengan Informan Kabupaten Bekasi pada tanggal 3 November 2019 Pukul 09.45 WIB.

${ }^{14}$ Ayi Darmana, Internalisasi Nilai Tauhid dalam Pembelajaran Sains, Medan : UNIMED, Volume XVII Nomor 1 2012/1433, 5. 
logis dari adanya keyakinan kepada Allah sebagaimana tercermin dari dimensi keyakinan. Adapun terkait, pertanyaan wawancara dimulai dari pertanyaan-pertanyaan dasar hingga merambat kepada pertanyaan yang lebih mendalam, misalnya: "apakah mereka menjalankan syariat agama (ibadah wajib dan ibadah lainnya) dalam kehidupan sehari-hari”, dan seterusnya. Salah seorang informan mengungkapkan panjang lebar di rumahnya disela-sela istirahat menjelang senja hari. Sambil ditemani secangkir kopi dan makanan ringan pembicaraan difokuskan kepada aspek praktik agama dalam sub ketaatan.

Hasil penelitian dapat mendeskripsikan dua hal: Pertama, para pekerja umumnya adalah indivuidu-individu yang taat dalam menjalankan praktik agama, seperti shalat. Mereka memahami betul bahwa salah satu kewajiban orang yang beragama adalah menjalankan perintah Allah dalam kondisi apapun. Kedua, meskipun mereka menyadari tentang kewajibannya sebagai seorang muslim harus menjalankan ajaran agama secara penuh, tetapi dalam kenyataannya masih terdapat yang "dilanggar". Makna dilanggar ini bukan berarti sengaja mengabaikan, tetapi hanya sebatas terlewat. Dalam pemahaman peneliti, tingkat kesadaran mereka pada dimensi praktik agama masih perlu ditingkatkan ${ }^{15}$.

\section{Dimensi Pengalaman Agama}

Dimensi ini berisikan dan memperhatikan fakta bahwa semua agama mengandung pengharapan-pengharapan tertentu, sehingga agak berat untuk diurai kepada hal-hal keagamaan yang sifatnya faktual. Pengalaman keagamaan tingkat tinggi berada pada suatu fase dimana seseorang mampu "bertemu" dengan dzat pencipta, dan ini hanya mungkin dilakukan oleh para sufi. pengalaman keagamaan ini.

Pada tingkat yang paling dasar misalnya, seluruh informan sepakat bahwa agama yang diimaninya mengandung pengharapan-pengharapan akan hari akhir, balasan akan kebaikan dan kesalahan, menempatkan Allah sebagai entitas untuk berkeluh kesah, dan sebagainya. Mereka sangat meyakini bahwa apabila di dunia beramal saleh dan menjalankan perintah agama maka mereka akan diberi balasan pada kehidupan yang akan datang, yaitu akhirat dengan ganjaran yang berlipat ganda.

15 Hasil Penelitian Lapangan yang diperoleh penulis dari Wawancara dengan Informan Kabupaten Bekasi pada tanggal 3 November 2019 Pukul 09.45 WIB 
Data yang diperoleh memberikan deskripsi bahwa sejatinya para pekerja menaruh harapan yang tinggi kepada agama baik untuk kehidupan di dunia maupun di akhirat. Mereka umumnya memahami bahwa ada balasan yang "indah" apabila berusaha sekuat tenaga dalam menjalankan perintah Allah. Pada aspek ini agama sejatinya mengandung pengharapan-pengharapan melalui ritual-ritual yang dijalankannya. Agama menjanjikan kebahagiaan, menawarkan suatu saat bertemu dengan kenikmatan. ${ }^{16}$

Menilik beberapa hasil wawancara tersebut dapat dikemukakan dua hal, yaitu: Pertama, mereka umumnya menyadari bahwa ada harapan-harapan atau keinginan-keinginan yang melandasi perilaku ibadah mereka. Mereka umumnya ingin atau berharap masuk surga sebagai balasan atas ibadah yang meraka lakukan. Itu mungkin dapat dikatakan normal-normal saja, artinya tidak luar biasa dan ibadah seperti itu dilakukan oleh banyak orang. Pengharapan itu juga memberikan deskripsi tentang sejauh dan sedalam apa pengetahuan keagamaan mereka. Pengetahuan mereka yang diperoleh dari para ustadz dilingkungannya hanya sebatas cara ibadah sebagaimana orang kebanyakan, yaitu mengharap surga dan menjauhi neraka.

Kedua, semua informan mengungkapkan bahwa amat jauh bahkan pesimis untuk sampai kepada pengetahuan subjektif. Mereka umumnya berpendapat bahwa pengetahuan subjektif hanya dimiliki oleh orang-orang yang derajat keimanan dan penghambaannya sangat tinggi, bahkan mungkin mereka yang sudah sampai pada derajat zuhud. Peneliti mengamati secara lahir, bahwa mereka tidak memiliki "tandatanda" yang dengan tanda-tanda itu mampu mengantarkan mereka kepada pengetahuan subjektif ${ }^{17}$.

Dalam tilikan peneliti melalui pengamatan, para pekerja memang menjalankan syariat agama tetapi tidak sampai kepada penyingkapan pengetahuan subjektif. Mereka hanya berusaha beribadah, menjalankan ritualitas, dan berharap mendapatkan balasan dari Allah. Untuk sampai kepada pengetahuan subjektif dibutuhkan pengetahuan dan pengamalan agama di atas orang biasa.

${ }^{16}$ Stephani Raihana Hamdan, Happiness : Psikologi Positiv Versus Psikologi Islam, Jurnal UNISIA Volume XXXVIII No 84 Januari 2016, 5-6.

17 Hasil Penelitian Lapangan yang diperoleh penulis dari Wawancara dengan Informan Kabupaten Bekasi pada tanggal 3 November 2019 Pukul 09.45 WIB 


\section{Dimensi Pengetahuan Agama}

Idealnya, seseorang yang memeluk suatu agama, misalnya seorang muslim melengkapi dirinya dengan beragam pengetahauan agama sehingga cara dan praktik ibadahnya memiliki landasan yang kuat. Dimensi pengetahuan juga yang akan memberikan ciri kuat seseorang mampu memahami (understanding) ajaran agama yang kerapkali rumit (complicated). Ajaran agama ada yang dapat dipahami melalaui domain nalar-rasional, tetapi juga ada yang hanya cukup diimani. ${ }^{18}$

Beberapa hasil wawancara di muka memberikan deskripsi bahwa pengetahuan keagamaan mereka sangat minimalis. Mereka pada umumnya memiliki pengetahuan yang terbatas, hanya sekedar mengetahui yang sifatnya dasar dan terkait dengan ibadah mahdhah. Realitas tersebut dapat dirasionalisasi pada dua hal: Pertama, memang mereka tidak banyak waktu luang untuk menuntut atau memperdalam ilmu agama. Mereka hanya disibukan oleh urusan pekerjaan sebagai pekerja pabrik dan urusan keluarga dan selebihnya digunakan untuk istirahat. Dalam pengamatan peneliti, jika mereka bekerja di siang hari, maka sore dan malam hari digunakan untuk istirahat dan keluarga atau bila mereka kebagian kerja malam, paginya selepas pulang kerja digunakan untuk istirahat dan mengurus keluarga.

Kedua, sejauh ini pihak perusahaan tidak menyediakan waktu bagi para pekerja (pekerja) mengadakan pengajian atau kajian-kajian keagamaan. Pihak perusahaan bertindak pragmatis, artinya perusahaan hanya mementingkan profit (laba) dengan cara "menekan" pegawai untuk bekerja sesuai SOP (standard operating procedur) yang ditetapkan secara rigit. Padahal bila teliti lebih dalam, kesadaran serta kebebasan beragama sangat penting untuk memperkokoh kepribadian pegawai sehingga dapat meningkatan kinerja perusahaan ${ }^{19}$.

\section{Dimensi Pengamalan (Konsekuensi)}

Dimensi ini mengacu kepada identifikasi akibat-akibat keyakinan keagamaan, praktik, pengalaman, dan pengetahuan seseorang dari

${ }^{18}$ Fakhruddin Aziz, Formula Pemeliharaan Agama (Hifdz Al-Din) Pada Masyarakat Desa Dermolo Jepara : Implementasi Maqashid al-Shari'ah dengan Pendekata Antropologi, Jurnal Al-Ahkam, Volume 27 Nomor 1 April 2017, 3.

19 Hasil Penelitian Lapangan yang diperoleh penulis dari Wawancara dengan Informan Kabupaten Bekasi pada tanggal 3 November 2019 Pukul 09.45 WIB 
hari ke hari. Artinya bagaimana agama menjadi bagian dalam perilaku sehari-hari, atau fungsionalisasi agama pada wilayah praksis. Sehingga idealnya, seseorang yang menjalankan agama dengan utuh (kaaffah) akan tercermin dari perilakunya sehari-hari. Seseorang yang beragama akan lebih bersikap hati-hati agar seluruh perilakunya dibimbing oleh ajaran agama.

Di tengah-tengah kehidupan yang banyak mempertontonkan kejahatan dikalangan elit, masih ada pikiran dari seorang pekerja pabrik yang mencerahkan dan menyejukkan. Seperti kata pepatah, bahwa kebaikan itu bisa datang dari mana saja, sebagaimana juga halnya kejahatan bisa datang dari siapa saja. Informan tersebut telah mampu mengaktualisasikan dan memfungsikan ajaran agamanya sampai kepada level pikiran dan perilaku. Inilah yang dimaksud dimensi konsekuensi (pengamalan agama) itu mewujud dan tumbuh pada realitas nyata. Pendapat informan-informan itu juga "membukakan mata" bahwa masyarakat kelas bawah memiliki kesadaran yang cukup dalam. Hal itu pula menjadi tanda bahwa masyarakat kecil jauh lebih peduli kepada penyakit yang namanya korupsi ${ }^{20}$.

Informan juga mampu secara secara analitik untuk membuat perbandingan dimensi konsekuensi agama pada wilayah sosial (social area), yaitu membandingkan kaum pekerja dengan perilaku para politisi dan pejabat negara. Hal itu menandakan bahwa mereka umumnya mengikuti perkembangan dan situasi-situasi terkini melalui media massa. Kondisi ini dirasa sangat baik guna memberikan pencerdasan bagi kaum pekerja yang kerapkali diasosiasikan sebagai masyarakat kelas bawah yang hanya berpikir tentang masalah perut saja.

Sebagai salah satu negara berkembang, Indonesia menjadi tujuan penanaman modal asing (PMA) yang bergerak dibidang industri berskala nasional bahkan mancanegara. Lepas dari persoalan industrialisasi yang tidak bisa dibendung, penelitian ini memfokuskan kajiannya kepada aspek kebebasan dalam menjalankan agama kaum pekerja dan Penerapan Undang-Undang Ketenagakerjaan Nomor 13 Tahun 2003 tentang Ketenagakerjaan dalam kebebasan menjalankan kewajiban beragama. Undang-undang ini secara tegas berbicara tentang Pengusaha wajib memberikan kesempatan yang secukupnya kepada pekerja/

20 Hasil Penelitian Lapangan yang diperoleh penulis dari Wawancara dengan Informan Kabupaten Bekasi pada tanggal 3 November 2019 Pukul 09.45 WIB. 
pekerja untuk melaksanakan ibadah yang diwajibkan oleh agamanya. Pada tataran operasional, Undang-undang Nomor 13 tentang Ketenagakerjaan tersebut diberi penjelasan sebagai berikut:

"Yang dimaksud kesempatan secukupnya yaitu menyediakan tempat untuk melaksanakan ibadah yang memungkinkan pekerja/pekerja dapat melaksanakan ibadahnya secara baik, sesuai dengan kondisi dan kemampuan perusahaan". ${ }^{21}$

Berdasarkan undang-undang beserta penjelasannya, maka pihak perusahaan wajib hukumnya untuk menyediakan sarana dan prasarana ibadah bagi seluruh karyawan seperti masjid, mushala, mukena, sarung, sajadah, tempat wudu, dan lain-lain. Di samping itu, pihak perusahaan juga wajib hukumnya memberikan alokasi waktu kepada para pegawai untuk menunaikan ibadah seperti shalat sehari-hari maupun shalat berjamaan di hari Jum'at.

Data yang dihimpun, direduksi dan dideskripsikan dapat memberikan beberapa temuan dan pemahaman mengenai Penerapan Undang-undang Nomor 13 Tahun 2003 tentang Ketenagakerjaan Dalam Kebebasan Menjalankan Kewajiban Beragama serta dimensi kesadaran beragamanya. Secara keseluruhan, perusahaan telah melaksanakan kewajibannya dalam menyediakan sarana dan prasarana ibadah meskipun pada beberapa perusahaan masih diperoleh data masih belum memenuhi tingkat kenyamanan.

Pada dimensi keyakinan agama, penelitian ini berhasil menghimpun data bahwa mereka (para pekerja) pada umumnya meyakini adanya Allah sebagai entitas yang harus diyakini dan sebagai landasan dalam berpikir, berperilaku dan bertindak. Para pekerja memahami bahwa keyakinan terhadap Allah merupakan landasan mereka dalam beragama yang membawa dampak kepada kesalehan pribadi dan kesalehan sosial. Islam mengajarkan bahwa kesempurnaan iman tidak saja dimanifestasikan melalui rangkaian ibadah ritual (vertical), tetapi juga diwujudkan melalui kesalehan sosial (horizontal).

Pada dimensi praktik agama, penelitian ini memberikan dua pemahaman mengenai perilaku praktik agama kaum pekerja. Pertama, para pekerja semampu dan sekuat tenaga melaksanakan kewajibannya dalam beribadah, meskipun dalam waktu yang sangat terbatas. Kedua,

Undang-Undang Republik Indonesia Nomor 13 Tahun2003 Tentang 
praktik agama merupakan perwujudan ketaatan kepada Allah yang tercermin dalam kehidupan sehari-hari dengan menjadikan agama sebagai pangkal tolak segala aktivitas.

Pada dimenesi pengalaman, para pekerja di dalam melaksanakan perintah agama (ibadah) memiliki pengharapan-pengharapan berupa pertolongan Allah baik di dunia dan di akhirat. Pada dimensi pengetahuan agama, penelitan ini dapat memberikian deskripsi bahwa secara umum pengetahuan agama para pekerja berada pada level biasa. Artinya bahwa pengetahuan agama mereka hanya sebatas ibadah ritual dan belum menjangkau kepada kedalaman tentang agama itu sendiri. Pada dimensi pengamalan (konsekuensi), para pekerja berusaha sekuat dan semampunya untuk berperilaku sesuai dengan tuntunan dan ajaran agama. Mereka menyadari bahwa setiap perbuatan yang dilakukannya memiliki konsekuensi yang berimbas kepada pencapaian kebahagiaan di dunia dan akhirat. Kesadaran ini juga yang menyebabkan mereka bersungguh-sungguh bekerja dan berusaha dengan harapan mendapat balasan kebaikan dari Allah.

\section{Simpulan}

Kebebasan menjalankan kewajiban beragama merupakan bagian penting bagi eksistensi manusia yang tercermin pada lima dimensi agama, yaitu keyakinan, praktik, pengalaman, pengetahuan dan pengamalan (konsekuensi). Berdasarkan hasil penelitian diperoleh kesimpulan: Pertama, Perusahaan-perusahaan yang menjadi tempat penelitian di Kabupaten Bekasi sudah menyediakan sarana dan prasarana ibadah sebagaimana diatur oleh Undang-undang Nomor 13 Tahun 2003 tentang Ketenagakerjaan Dalam Kebebasan Menjalankan Kewajiban Beragama. Namun demikian di sisi lain, para pekerja masih mengharapkan perbaikan kualitas dan kuantitas sarana ibadah sehingga dapat menjalankan ibadah lebih nyaman; dan

Kedua, Secara umum, kesadaran beribadah para pekerja berada pada tingkat atau level biasa. Artinya, bahwa benar mereka beriman kepada Allah dengan pengetahuan keimanan yang minimal. Mereka juga melaksanakan praktik agama sebagai bukti dari keimanan itu sendiri dan sebagai bukti ketaatan kepada Allah. Para pekerja dalam melaksanakan perintah agama (ibadah) dibarengi dengan pengharapan-pengharapan akan ganjaran (balasan) sehingga mencapai kebahagiaan di 
dunia dan akhirat. Namun demikian para pekerja menyadari bahwa ibadah yang dilakukannya saat ini tidak akan sampai kepada pengetahuan subjektif (dialog dirinya dengan kekuatan supranatural, yaitu Allah). Para pekerja juga berusaha untuk menjadikan agama sebagai landasan dalam seluruh perbuatan, karena perbuatan apa pun yang dilakukan oleh seseorang yang beragama akan membawa konsekuensi bagi kehidupannya di dunia dan di akhirat kelak.

\section{DAFTAR PUSTAKA}

Aziz, Fakhruddin, Formula Pemeliharaan Agama (Hifdz Al-Din) Pada Masyarakat Desa Dermolo Jepara : Implementasi Maqashid al Shari'ah dengan Pendekata Antropologi, Jurnal Al Ahkam, Volume 27 Nomor 1 April 2017.

Bauto, Laode Monto, Perspektif Agama dan Kebudayaan dalam Kehidupan Masyarakat Indonesia (Suatu Tinjauan Sosiologi Agama), Jurnal Pendidikan Ilmu Sosial Volume 23 Nomor 2 Edisi Desember 2014.

Darmana, Ayi. Internalisasi Niai Tauhid dalam Pembelajaran Sains, Medan : UNIMED, Volume XVII Nomor 1 2012/1433.

Hakim, M. Arif, Industrialisasi di Indonesia Menuju Kemitraan yang Islami, STAIN Kudus. (t.th)

Hamdan, Stephani Raihana, Happiness : Psikologi Positiv Versus Psikologi Islam, Jurnal UNISIA Volume XXXVIII No 84 Januari 2016.

Moleong, Lexy. J. Metode Penelitian Kualitatif. Bandung: PT. Remaja Rosdakarya. 2006.

Muhayati, Siti. Christiana, Ratih, dkk, Iman kepada Allah dan Perhatian Orang Tua Terhadap Budaya Nyontek Anak Usia Sekolah Dasar, Jurnal Bimbingan dan Konseling,

Saleh, B. dan Warlina, L., Identifikasi Karaktreristik Aglomerasi Industri Pengolahan di Cikarang Kabupaten Bekasi Tahun 2006-2013, Jurnal Wilayah dan Kota, Volume 4 Nomor 1.

Suhardin, Yohanes, Peranan Negara dan Hukum dalam Memberantas Kemiskinan dengan Mewujudkan Kesejahteraan Umum, Jurnal Hukum dan Pembangunan Tahun ke-42 No.3 Juli-September 2012. 
156 | Adliya: Jurnal Hukum dan Kemanusiaan, Vol. 14, No. 1, Juni 2020

Suhendri, Pengaruh Keberagaman Tenaga Kerja dan Lingkungan Kerja Terhadap Kinerja Karyawan (PT. Parkland World Indonesia Plants 2), STIE Prima Graha.

Undang-Undang Republik Indonesia Nomor 13 Tahun2003 Tentang Ketenagakerjaan. 